\title{
AN APPROACH TO THE UNDERSTANDING OF SPORTS CIVIL ORGANIZATIONS’ ACTIVITY AND MANAGEMENT IN HUNGARY
}

\author{
Sándor KOVÁCS ${ }^{1}$, Éva BÁCSNÉ BÁBA (D2 2*, Zoltán BÁCS ${ }^{3}$, Károly PETŐ ${ }^{4}$, \\ Veronika FENYVES ${ }^{5}$, Kushtrim VLLASAJ ${ }^{6}$, András HELMECZI ${ }^{7}$, \\ György Norbert SZABADOS ${ }^{8}$ \\ ${ }^{1}$ Institute of Sectoral Economics and Methodology, University of Debrecen, \\ Böszörményi út 138, H-4032 Debrecen, Hungary \\ 2, 6, 8 Institute of Sports Economics and Management, University of Debrecen, \\ Böszörményi út 138, H-4032 Debrecen, Hungary \\ 3, 5 Institute of Accounting and Finance, University of Debrecen, \\ Böszörményi út 138, H-4032 Debrecen, Hungary \\ ${ }^{4}$ Institute of Rural Development, Tourism, University of Debrecen, \\ Böszörményi út 138, H-4032 Debrecen, Hungary \\ ${ }^{7}$ Institute of World Economy and International Relations, University of Debrecen, \\ Böszörményi út 138, H-4032 Debrecen, Hungary
}

Received 20 November 2020; accepted 27 August 2021

\begin{abstract}
Sports civic organizations are essential for Hungarian society, especially for young people's lives, constituting a crucial part of the corpus of civil society organizations. The performance and output of these were rarely examined; still, activity forms of an organization and their managerial practice may equally result in failure and success. By applying a survey questionnaire, this study provided an in-depth picture and an analysis of the six crucial dimensions of their functioning: Public Activity, Employment, Human Resources, Professional Activity, State Aid and Funding, and Social Influence. Apart from the contribution that this study gave to recognize a particular type of civil society organizations, i.e., the sports one, its significance lay mainly in the connection of the crucial attributes/dimensions of organization and functioning.
\end{abstract}

Keywords: sports, civil organizations, public, professional, HR, funding, influence.

JEL Classification: L31.

\section{Introduction}

Sports activities have long been a form of community attraction towards participation, inclusion, and social integration. Especially for the youth, sport is a consistent activity of physical

*Corresponding author. E-mail: bacsne.baba.eva@econ.unideb.hu

Copyright (c) 2022 The Author(s). Published by Vilnius Gediminas Technical University

This is an Open Access article distributed under the terms of the Creative Commons Attribution License (http://creativecommons. org/licenses/by/4.0/), which permits unrestricted use, distribution, and reproduction in any medium, provided the original author and source are credited. 
and mental development of the individual and the group, therefore the organization and planning of which is of great importance for society and the economy as a social domain. The engagement of young people in organized sport is a steady concern for both national and international sport-governing bodies because youths are seen as vital to the sustainable management of sport organizations (Strittmatter et al., 2021). In the context of sectors, the regulation of these organizations may be of a private, public, and voluntary nature. Still, in this study, only the latter will be taken into account. As organizations in western countries and beyond, sports civil society organizations occupy a very large part in the non-profit sector of civil society. Sports civil organizations' research is not new as many researchers have contributed to their explanation from different aspects and areas of study, mainly sociological. For example, Seippel has consistently dealt with voluntarism, social capital, sector networks, potential influence, social integration, and many other topics concerning sport civil organizations (Seippel, 2004, 2005, 2006). Altough their study was of great importance from the aspect of functioning, organizing and management, the development and progress of the sector have remained scarce so far. While the management of for-profit sports organizations is concerned mainly with the protection of the shareholders' interests, especially the owners, the management of non-profit sports organizations focuses more on the cause to serve, bring together and involve the community, especially the youth, and spread the charity or good-will spirit from the organization towards a wider scope.

The management of organizations, whatever they may be, cannot be presented properly without involving the merging or combination of several different factors, which are nevertheless interrelated. The first necessary step to have a more accurate and clearer picture of the management of civil sports organizations is to include some key attributes or dimensions, which constitute the framework of their functioning. Therefore, this paper's approach will be established in six main dimensions, together with their interrelations, derived from the six survey blocks, including 35 items (separate questions). These dimensions include Public Activity, Professional Activity, Employment, Human Resources, State Aid and Funding, and Social Influence. A Categorical Principal Component Analysis (CATPCA) model has been performed to form a proper structural path model from these six dimensions. CATPCA as analysis has also been used recently by Saukani and Ismail (2019), where they similarly analyzed the identified components of social capital expressed in variables of mixed measurement levels. The objective of this study was to get a better understanding of how different activities interrelate, what were their relationships, and how to treat this complexity of activities as a whole. We also desired to answer the following question: "what is the relationship between the organizational activities and how the different organization activities are interrelated with organizational success". This is also a missing topic in the field of the discipline of Management since scientific achievements usually focused on a specific managerial task or function and not really the interdependence of the functions themselves. For example, with better funding possibilities, an organization could get access to better employment conditions, which might result in an enhanced social influence. Since this sector is highly pervaded by the subsidies, a better utilization of the resources is vital. By identifying the relationships between the primary activity forms, a particular emphasis might be given to the more influential ones, and also the way of interactions starting from the interventions can be 
mapped. The major aim of the article was to study the complexity of the activity relationships throughout the six dimensions.

The article is organized as follows. The introduction introduces the importance of the topic and the research gap. Section 1 discusses and interprets the basic terms and their related activity forms in the framework of the literature review with special focus on the Hungarian specifications. Section 2 describes the materials and applied methods. Section 3 presents the results in connection with the research specifications. Some conclusions are drawn together with the limitations and possible future directions of the research in last Section.

\section{Literature review}

\subsection{The approach and concept of sport civil organizations with an insight into the activity forms}

Although still called the third sector, civil society and its organizations play currently an important role in society. Around the world, civil society proved its value and made a difference. People's experience of the pandemic would have been much worse without the civil society response (World Alliance for Citizen Participation [CIVICUS], 2021). The "civil society" (or third sector) definition is broad and can cover any "actors" from sports clubs to neighborhood communities that are neither private nor governmental (Vosyliūte \& Luk, 2020). Civil Society Organizations (CSO) include organizations that were recognized in the literature as being non-governmental, non-profit, and private. Another typically referred term with similar content was named non-governmental organizations (NGOs) (European Commission, 2020). Although they are organized as private, self-governed and non-profit, Salamon and Anheier (1992) have identified and emphasized the right to another essential element: volunteering. Undoubtedly, volunteering is an inseparable feature when this sector is taken as a whole; however, there are special cases where this feature is not present. According to O’Neil (1989), civil society and its organizations serve a public purpose and contribute to a good society. They deliver actions in the fields of empowerment of women, civic engagement, community development, human rights, community peacebuilding, conflict resolution, health and sports (Natil et al., 2021). Among them, various organizations affect almost all areas of life, and their division or classification is not always easy. However, when it comes to the classification of these organizations in terms of their scope and general nature of activities, a large part of them is occupied by various organizations concerned with sports and recreation activities. They are arenas, where sport brings people together in different forms. Nicholson and Hoye (2008) noted that except for facilitating and watching, playing sport was one of the three forms of sport engagement. Being the leading providers of sports, not only in Hungary but also in other countries, these organizations were intended exclusively to serve their members. However, they were thought to be less specialized and more complicated in terms of management structure (Horch, 2018). Sports civil organizations, or as Auld and Cuskelly (2012) referred to them as non-profit sports organizations (NSOs), were formed in such a way that their mission was not profit. However, they could generate income which they reinvest in organizations and generally depend on volunteering. 
In this study only the six most important attributes were discussed. The literature review part was developed by explaining these attributes and noting how far the authors have gone with previous studies with each of them, regarding CSOs, especially those related to sports. The discipline of management usually approached the topic of managerial activities as a composition of 4 different functions: planning, organizing, leading and controlling (Griffin, 2013; Daft, 2010; Robbins \& Coulter, 2012). Nevertheless, most of the applied 19-22 chapters in Griffin (2013) dealt usually with functions, which did not typically reflect the operations of these kind of organizations under the Hungarian conditions. The activity categories below are crucial activity forms in domestic organizations, which equally cover the statistical points of interest (Központi Statisztikai Hivatal [KSH], 2018). The Hungarian Central Statistical Office (abbreviated as KSH in Hungary) annually publishes the most important specifications of the Hungarian non-profit organizations, including the NSOs as well. We must emphasize that owing to the lack of private empirical surveys in this field, this report, together with its published database, was the only one to provide information about the sector. This database was based on the compulsory self-record upload of the non-profit organizations annually into the system called ELEKTRA, run by the Statistical Office. The annual report's professional information categories were partially our categories as well: The professional Activity, Employment, Human resources (these two latest are also differentiated in the report), State Aid. The additional two categories, Public Activity and Social Influence, were conceptualized with respect to the international standards on social responsibility, Hemphill (2013). The studied organizations still operate in a strong relationship with the community. Their activity serve the interest of the public sphere, and their influence on society usually reflect more than simply their relationship and activity. The major categories examined were the economic relations (such as subsidies), human resources) and the stakeholder approach that were activity forms, and their impact on the society itself. Hemphill (2013) had identified 7 core subjects of social responsibility such as business governance, human rights, labor practices, environment, fair operating practices, consumer issues, community involvement and development. To develop the article's dimensions effecting social influence, item lists in Robertson's et al. (2019) study were also mapped and adapted in Hungarian circumstances. Public activity is like community involvement, employment dimension is equivalent to labor practices, professional activity is part of the governance, state aid and funding is analogous to economic dimension.

Public Activity. Concerning civil society, different authors gave different extensions to the word "public". One of the best known was Habermas (1989), who defined the public sphere as the sphere of private people who gathered as public in front of the public authorities to engage themselves in a debate over the governing rules. Based on similar theories, other authors later attempted to elaborate on the relationship between the concept of civil society and the public sphere. Although Calhoun (1993) for example, insisted that these two terms should not be seen as synonymous, as the concept of the public sphere went beyond general appeals to the nature of civil society. Still, the linkage between them is enormous.

Regarding non-profit sports organizations specifically, they and their observers pointed out that sports can be considered to be of public interest and the means of education and social development (Soares et al., 2016). Sports organizations, as part of civil society organi- 
zations, suit public issues; therefore, their activities are the same. Their relationship with the public is essential when it is about management, human resources, or the organization as a whole. Publicity and transparency are crucial for their necessary communication with the public as well as with partners, mainly because of their programs, whether regular or special.

Professional Activity. In general, professionalism in the operational life of CSOs is essential and has a huge impact on their reputation, although the way it is evaluated and measured can be very subjective. For the stability and expansion of organizations, their activities must be planned and developed based on the plan and with certain methods to move towards a more professional stage. Helmig et al. (2004) noted that one factor that has raised the need to move from an amateur approach to a more professional management system was the challenge of fundraising and donations, which declined from time to time. In sport civil organizations, from the results of sports activities to other non-sports activities, from articles published by the organization to the official website or even profiles on Facebook, all of them can be considered as important and active relationships with their partners.

Employment. In the absence of funds, donations and the inability to develop their activities, as a substitute, civil society organizations recovered a significant portion of their energy from volunteering, which nowadays cannot be easily found. A study conducted by Osterlund (2013) established on the management perspective of voluntary sports s organizations, specifically in recruiting volunteers and the results of the relationship between management and volunteer recruitment offer recommendations for further improvement. According to a report by Breuer et al. (2017), in sport organizations in Hungary, there was one volunteer from approximately five members. In proportion relative to members, there were $22 \%$ of volunteers in fixed positions and $16 \%$ not in fixed positions, while the proportion of paid staff was only $2 \%$. Besides paid work also played an important role, Dajnoki et al. (2020) reiterated the importance of volunteering as the main feature of employment in the civil society sector.

Human Resources. Human Resources fairly constituted a large part of the study of CSOs (for example, a quick search on Google Scholar showed that of the 1.29 million findings, 0.6 million was about the HR specifications about CSOs.) Their management should be an art, given how vital, complex, and unique they are. At this point, sports organizations made no exception (in Google Scholar, 68.5 thousand findings dealt with the topic of human resources regarding NSOs). In a study conducted by Seippel (2004) in Norwegian sports organizations, which indicated the main problems faced by volunteer sports clubs, the most pronounced issues were those related to human resources. Namely about $40 \%$ were related to the lack of volunteers, lack of leaders, and lack of trainers. Of these, especially the recruitment of a sufficient number of volunteers remained the main challenge of voluntary sports organizations (Ibsen, 2006). However, regarding Human Resources, this study was reduced to three main items: the availability of workers, the overall organizational culture, and staff fluctuation.

State Aid and Funding. For the existence of many civic organizations including sportsrelated ones, State Aid and other funds are the main conditions without which most of them cannot survive. Sport development and sporting events were in the focus of interest of the local and central governments, which allocated a part of their budget to sports financing (Andreff \& Szymanski, 2007). In their work on sport economics they argued that there was no update of the European Council's survey. They also stated that Hungary was among 
the countries in the 1990s where the public and private funding of sport was almost equal (public: $46.8 \%$, private: $53.2 \%$ ). Hungary was quite a unique country of the other surveyed European countries, since here the contribution of the central government was almost the double compared to the local governments. The authors claimed that there might have been a political reason for the limitation of the central government's budget for sports compared to other sources of sports financing. A more centralized administration of sports in France, Italy, Portugal and Hungary (and to a lesser extent the Czech Republic) resulted in a more significant share of the state budget in the overall sports finance. Regarding the recipients, finance mostly went to sport clubs in all over Europe, except the UK, where $85.3 \%$ of the funds went to financing federations.

According to the Global Humanitarian Assistance Report, NGOs absorbed approximately $20 \%$ of government funds worldwide and intended for humanitarian aid (Development Initiatives, 2015). Andreff (2009) claimed that on average, 36\% of sports ministries' funding went to financing sport federations and other sport organizations on the European level. In contrast, government donations and subsidies provided $43 \%$ of NGOs' income in Hungary (this ratio for so-called classical civic organizations was 45\%, and for sport NGOs' profiles 60\%) (KSH, 2018). Therefore, State Aid and Funding are irreplaceable factors for CSOs. There are two main types of sources of funding, internal (donations or contributions from members, payments to sponsors, or even profit at the incomes) and external (government grants, material donations, donations from embassies, grants from larger NGOs, often international NGOs, independent individuals for humanitarian purposes).

However, the best would be if the funds were diversified into more than one source, which would help financial and organizational sustainability. According to Lynn (2013) the more different sources of funds were available, the more financially sustainable a CSO was. Wicker et al. (2015) dealt with the diversification of the revenues of sport clubs in Germany by identifying 25 different types and pointed out that non-profits in sport tended to have more diversified revenues. They argued that a relatively high number of income sources could ultimately lead to higher levels of diversification or a variety of income sources of sport clubs as a result of heterogeneous stakeholders. Their empirical results showed that the level of revenue diversification differs among sport clubs and depends on the type of organizational mission. Cordery and Baskerville (2011) claimed that generating sufficient funding from a diversity of revenue streams is a critical issue for non-profit sport organizations. Their work stemmed from the pioneering study of Tuckman and Chang (1991), who found that nonprofit organizations with few revenue sources were more financially vulnerable than those with many sources. The authors finally concluded that most clubs sought revenue from "traditional" means and were risk-averse rather than being risk-takers when it came to revenue diversification.

Social Influence. One of the phenomena, perhaps the main one that characterizes civil society organizations, is their influence on society. Weber (1993) defined influence as the affection of one set of actors to the others. Such effects also have the activity of sport organizations that serve as a scene of community association against discrimination and segregation. In an excellent way, this was illustrated by Ekholm and Dahstedt (2019), who examined the formation of a Swedish sport-based association-like organization where the sport was con- 
ceptualized as a way of social inclusion as a response to traditional ethno cultural divisions, exclusions, and conflicts. The development or improvement could be in different forms and aspects and can have sometimes smaller and sometimes larger effects, depending on the organization's realization and its performance. In this paper, Social Influence was limited and divided as a measure into three units based on the effects and relationships. There were local and global social effects as well as the relationship with the local society.

\subsection{Sport civil organizations in Hungary and previous research}

Although research on civil society and sport organizations in Hungary is not extensive and do not affect all branches of the study, it still cannot be said that no work has been done in this direction. Reviews on sport civil organizations can also be found in the working papers of John Hopkins comparative non-profit sector by Salamon and Anheier, where Kuti (1993) generally defined the non-profit sector in Hungary. Regarding sport organizations they were described as belonging to voluntary organizations in the classical sense, which were even tolerated and supported during the 60 s and 70 s after the tensions of the time of Stalinism calmed down. During the late 1990s, the sports organizations existed as private companies, which were later re-established as joint-stock companies, nevertheless paying attention to membership (Bodnár \& Perényi, 2012). Meanwhile, the first 20 years of democracy were interpreted as a phase where the policy of establishing a relationship between the state and civil society through sport was not getting the attention it deserved. Thus, civil society organizations found it difficult to build an environment that would establish a stable relationship, especially with the frequent change of governments at that time (Perényi \& Bodnár, 2015). The changes in the law on Sports (Act CLXXII, 2011) together with the changes in the political approach towards the development of sports further strengthened the position of all citizens to access sports at all stages. Civil sport organizations undoubtedly experienced a development and a growth in terms of participation and membership, which also brought new financial resources and funds after 2010. Nowadays, sport clubs in Hungary take a vital place in guaranteeing civic decision-making as an instrument of strengthening democracy. Sport clubs also create options for sport services and serve as a place where marginalized groups can find space for inclusion. Perényi (2020) stated that most clubs are a place for elite and competitive athletes. Even though most clubs aim to involve members in decisionmaking procedures, volunteers are mainly in fixed positions. Sporting facilities are generally owned by municipality-owned companies or by schools, so sport clubs have to pay the rent only when they use them. The number of these organizations and their involvement was greater compared to previous periods, and in this context, there was a development (Perényi, 2020), currently including 9693 organizations, where sports are the major activity form, constituting $15.8 \%$ of the whole NGO sector (KSH, 2018). It is necessary to remark that the so-called classic civic organizations (associations and foundations) among the NSOs constitute $97.8 \%$ of the whole. The modified Act on sports (Act CLXXII, 2011) allowed these two types of organizations primarily to be called "civic". However, despite the growth of this sector in Hungary, the situation has changed from an international perspective. According to the report of the European Commission (2018) Hungary remained one of the lowest among 
European countries with respect to participation and membership in sports organizations. In fact, the University of Debrecen regularly works for enrich the literature of sport civil organizations. For example, Kozma (2017) took the opportunity to study the spatial characteristics of non-profit sports organizations in terms of number, income, and employment conditions of organizations. Moreover, from the viewpoint of functioning as an organization, the analysis was also based on external factors. In sport activities and in such organizations, external factors as region and population were also studied and the engagement of the respondents, the commitment factors, club loyalty determinants and the attendance aspects were also described (Bácsné Bába et al., 2018).

In another work concerning employment, Szabados et al. (2019) revealed the relationship between subsidies and human resources in civil society sport organizations and found that subsidies of a private nature has a high impact on volunteering work-related employment. In the latest studies, the examination of control as a managerial function has led to the further understanding that a large number of sport organizations in Hungary do not perform according to their forecasts due to the high dependence on subsidies (Szabados et al., 2020).

\section{Methodology}

\subsection{Data and pre-processing}

Considering the methodology technique, a questionnaire was applied to meet the specific features of the sport civic organizations. The questionnaire was structured into six blocks/ dimensions (Public Activity, Employment, Human Resource, Professional Activity, State Aid and Funding, Social Influence) involving 35 items (separate questions) measured on an ordinal, Likert or a dichotomous scale. As discussed earlier, item development was generally based on international standards and relevant research papers (Hemphill, 2013; Robertson et al., 2019). Items inside the activity categories were also edited by following the relevant information and data inside the specific sources of the Activity forms provided by the KSH annually.

Regarding the sampling method, there were different approaches to the availability of civic organizations in Hungary. All the Hungarian civic organizations were required to register after the establishment at court. Although this database was certified officially (by the Act CLXXXI of 2011 on court registration and related procedural rules of Civic organizations), the availability of the sport civic organizations' list was blocked. From the summer of 2019, the download of data of the civic organizations had also been blocked by the Captcha system, which made it practically impossible to assemble a database. The KSH also collects data on civic organizations in accordance with the legislative requirements. However, a detailed and adequate database is almost impossible to get. On the other hand, a general database about the main features of the civic organizations is still available but not appropriate for this specific research. The Opten System also assembles and bears a database of the Hungarian civic sector, where 12120 domestic, sport profile non-profit organizations are also available. From this database, meeting settlement and county-related representativeness, 1000 sport profile civic organizations were selected. Respondents (organization representatives' availability were provided by the system) were surveyed by Computer Assisted Telephone 
Interviewing (CATI). Data were recorded into SPSS system. The data consisted of 1000 civil organizations based on the criteria for sample sizes proposed by leading authors in the field of partial least squares (Sanchez, 2013; Hair et al., 2014; Esposito Vinzi et al., 2010). As the suggested minimum sample for path analysis is of 200 individuals, our sample size could be considered sufficient for further analyses. Data did not contain any mistyping or unusual values, and there was no case of multicollinearity (situation in which independent variables in a regression are strongly correlated). Multicollinearity of the latent variables (Table 2) was measured by the variance inflation factor (VIF), which measures the increased variance of a variable due to the stronger correlation to the other variables. VIF values were calculated with respect to Social Influence, Human Resources and Professional Activity as dependents using "olsrr" package in R software (R Core Team, 2019) and were less than the suggested limit of 3.0 (Garson, 2016). The percentage of missing data in the case of all manifest variables was lower than $10 \%$ (Table 2), and missing data in a given manifest variable were imputed by the median of that manifest variable using the mice (Multivariate Imputation by Chained Equations) package in R software (R Core Team, 2019).

\subsection{Applied methods}

The authors' major goal was to develop a structural path model. Some data reduction should be applied in order to form more comprehensive blocks within the model. The standard Principal Component Analysis (PCA) cannot be applied to categorized data; therefore, a preliminary CATPCA has been employed to clear unnecessary items by using principals function in "Gifi" packages (R Core Team, 2019). Firstly, CATPCA rescales the categorized data to a numerical variable applying the optimal scaling method, then performed a reduction on the number of variables in the data as described above similarly to standard PCA (Linting et al., 2007). Optimized scaling assigns numerical values for each category and these optimally scaled values can be used during PCA assessment. The aim of the PCA is to combine the variables that are correlated with each other into one common principal component. Different measurement level - nominal and ordinal level as well - variables can also be used in the assessment without any preliminary restrictions, and the values are assigned during an iterative method called Alternating Least Squares to the categories (Linting et al., 2007). The analysis of the final path model involved a special statistical technique called Structural Equation Modelling with Partial Least Squares (PLS-SEM) (Wold, 1982, 1985; Chin, 1998). The construction of the model was based on the blocks identified by the CATPCA analysis. The purpose of the analysis was to graphically represent the manifest items in a two-dimensional map and study the more robust connections between them. For conceptual reasons, those items were left out of the model, which had low factor loadings. Several research activities suggest PLS-SEM analysis as a particularly useful tool for index construction. Although either the formative model (Arnett et al., 2003; Fornell et al., 1996) or the reflective way of modelling LVs (Diamantopoulos, 1999) could be supported, the reflective model was used for index construction. A global criterion of Goodness-of-Fit (GOF) (Amato et al., 2004) was applied to evaluate the overall model and bootstrapping for model testing, according to Chin (1998). The GOF of $0.10 ; 0.25 ; 0.36$ can be considered an adequate, moderate and 
good global fit (Wetzels et al., 2009). A normalized version of the GOF (Esposito Vinzi et al., 2010) was also estimated for measuring the quality of the inner and outer model as well. The composite reliability of the blocks was tested by the Dillon Goldstein's rho indice. The identified dimensions had reliability above the recommended 0.7 , and most of the factor loadings were also greater than 0.6-07 (Hair et al., 2014). The assessment of structural model quality was measured by $\mathrm{R}^{2}$. The values of $0.02 ; 0.15 ; 0.35$ are considered small, medium or large effects, according to Cohen (1988). Fornell and Larcker criterion was be applied (Fornell \& Larcker, 1981) to assess discriminant validity of the model, suggesting that Average Variance Extracted (AVE) of a Latent Variable (LV) was higher than the amount of variance explained in another LVs by this latent construct. The model fit and calculations were performed "plspm" (Partial Least Squares Path Modelling) package in R software (Sanchez, 2013; R Core Team, 2019).

\section{Results and discussion}

The sample (most important details of which are illustrated on Table 1) contained 1000 civil sports organizations $97 \%$ of which were associations. Regarding the location, the capital dominated the sample (40\%), and the second most frequent location was the village or small town $(38 \%)$.

Table 1. Descriptions of the civil organizations by orientation, target, financial status and location

\begin{tabular}{|l|l|c|c|c|c|}
\hline \multirow{2}{*}{ Factor } & \multicolumn{1}{|c|}{ Description } & \multicolumn{4}{|c|}{ Legal status } \\
\cline { 3 - 6 } & & Association & Foundation & Civil society & Total sample \\
\hline \multirow{3}{*}{ Orientation } & $\begin{array}{l}\text { Professional sport } \\
\text { oriented }\end{array}$ & $39.5 \%$ & $0.0 \%$ & $25.0 \%$ & $39.0 \%$ \\
\cline { 2 - 6 } & $\begin{array}{l}\text { Nonprofessional sport } \\
\text { oriented }\end{array}$ & $60.5 \%$ & $100.0 \%$ & $75.0 \%$ & $61.0 \%$ \\
\hline $\begin{array}{l}\text { Financial } \\
\text { status }\end{array}$ & Non-profit oriented & $24.3 \%$ & $83.3 \%$ & $11.1 \%$ & $24.9 \%$ \\
\cline { 2 - 6 } & Non-charitable & $75.7 \%$ & $16.7 \%$ & $88.9 \%$ & $75.1 \%$ \\
\hline \multirow{3}{*}{\begin{tabular}{l} 
Location \\
\cline { 2 - 6 }
\end{tabular}} & Village/Small town & $38.4 \%$ & $28.6 \%$ & $22.2 \%$ & $38.1 \%$ \\
\cline { 2 - 6 } & Town, but not shire-town & $11.2 \%$ & $14.3 \%$ & $0 \%$ & $11.2 \%$ \\
\cline { 2 - 6 } & Shire-town & $11.1 \%$ & $0 \%$ & $11.1 \%$ & $11.0 \%$ \\
\hline Capital & $39.2 \%$ & $57.1 \%$ & $66.7 \%$ & $39.7 \%$ \\
\hline \multirow{2}{*}{ Distribution } & & $97.4 \%$ & $1.4 \%$ & $1.2 \%$ & - \\
\hline
\end{tabular}

Note: Total sample size equals 1000 ; the total is $100 \%$ across each individual factor.

At the first stage of the analysis, a preliminary CATPCA analysis was performed on all the items in order to reveal the relevant blocks of items and reduce the dataset to achieve better composite reliability. The relevant six blocks identified can be seen in Figure 1.

The 6 blocks altogether contained 35 items, but after the application of CATPCA, the number of items could be decreased to 21 according to Figure 1, which illustrates the established blocks if only 2 dimensions were created. The best-correlated items were selected 


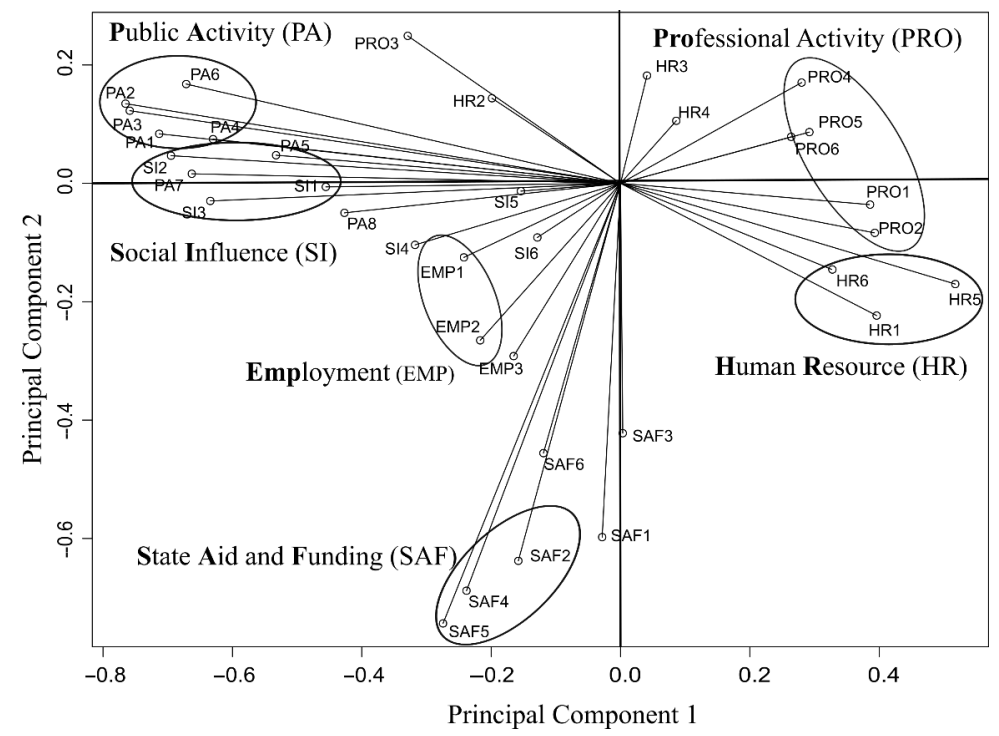

Figure 1. The 2-dimensional solution of the CATPCA method (source: own compilation)

to form a block in the path model (Table 2). The third employment item (Volunteers) was omitted from the final model because the loading was less than 0.4 .

The axes were the Principal Components, which were a linear combination of the variables related to them. The points represent variables, and long vectors running from the origin to points close to an axis indicate a stronger correlation with that given axis. Correlations can be either positive or negative, and even opposite variables can also be detected. For instance, Public (PA) and Professional Activity (PRO) were strongly related to the first Principal Component but negatively correlated with each other. State Aid and Funding (SAF) could be associated with the second Principal Component. In Figure 1, six ellipses showed the groups of variables that were strongly connected and tended to move together. For example, Professional Activity (PRO) block tended to move together with Human Resources (HR), and Public Activity (PA) was associated with Social Influence (SI).

Table 2. Descriptive statistics, loadings and composite reliability of the studied items

\begin{tabular}{|c|c|c|c|c|c|c|c|c|}
\hline Item & $\begin{array}{c}\text { Latent } \\
\text { variable }\end{array}$ & $\begin{array}{l}\text { Manifest } \\
\text { variables }\end{array}$ & $\begin{array}{l}\text { Scale } \\
\text { type }\end{array}$ & $\begin{array}{c}\text { Median/ } \\
\text { the ratio } \\
\text { of Yes } \\
\text { answer } \\
(\%)\end{array}$ & $\begin{array}{l}\text { Inter- } \\
\text { quar- } \\
\text { tile } \\
\text { Range }\end{array}$ & $\begin{array}{c}\% \text { of } \\
\text { miss- } \\
\text { ing } \\
\text { cases }\end{array}$ & $\begin{array}{l}\text { Load- } \\
\text { ing }\end{array}$ & $\begin{array}{l}\text { DG } \\
\text { rho }\end{array}$ \\
\hline General activity & \multirow{4}{*}{$\begin{array}{l}\text { Public } \\
\text { Activity } \\
\text { (PA) }\end{array}$} & PA1 & \multirow{4}{*}{$\begin{array}{l}\text { Likert } \\
(1-5) \\
1: \text { negli- } \\
\text { gible; } \\
5 \text { : very } \\
\text { signi- } \\
\text { ficant }\end{array}$} & 4.20 & 1.45 & 2.3 & 0.805 & 0.891 \\
\hline $\begin{array}{l}\text { Management } \\
\text { activity }\end{array}$ & & PA2 & & 4.29 & 1.47 & 3.8 & 0.828 & \\
\hline $\begin{array}{l}\text { Regular } \\
\text { programmes }\end{array}$ & & PA3 & & 4.48 & 1.22 & 2.4 & 0.873 & \\
\hline $\begin{array}{l}\text { Special } \\
\text { programmes }\end{array}$ & & PA4 & & 4.01 & 1.57 & 8.5 & 0.702 & \\
\hline
\end{tabular}


End of Table 2

\begin{tabular}{|c|c|c|c|c|c|c|c|c|}
\hline Item & $\begin{array}{c}\text { Latent } \\
\text { variable }\end{array}$ & $\begin{array}{l}\text { Manifest } \\
\text { variables }\end{array}$ & $\begin{array}{l}\text { Scale } \\
\text { type }\end{array}$ & $\begin{array}{c}\text { Median/ } \\
\text { the ratio } \\
\text { of Yes } \\
\text { answer } \\
(\%)\end{array}$ & $\begin{array}{l}\text { Inter- } \\
\text { quar- } \\
\text { tile } \\
\text { Range }\end{array}$ & $\begin{array}{l}\% \text { of } \\
\text { miss- } \\
\text { ing } \\
\text { cases }\end{array}$ & $\begin{array}{c}\text { Load- } \\
\text { ing }\end{array}$ & $\begin{array}{l}\text { DG } \\
\text { rho }\end{array}$ \\
\hline $\begin{array}{l}\text { Human resource } \\
\text { activity }\end{array}$ & & PA6 & & 3.72 & 1.79 & 3.7 & 0.722 & \\
\hline $\begin{array}{l}\text { Good results } \\
\text { from sport } \\
\text { activities }\end{array}$ & \multirow{5}{*}{$\begin{array}{l}\text { Professional } \\
\text { Activity } \\
(\mathrm{PRO})\end{array}$} & PRO1 & \multirow{5}{*}{$\begin{array}{l}\text { Dichoto- } \\
\text { mous } \\
\text { (Yes-No) }\end{array}$} & 84.60 & \multirow{5}{*}{-} & 0.2 & 0.666 & 0.715 \\
\hline $\begin{array}{l}\text { Good results } \\
\text { from other } \\
\text { activities }\end{array}$ & & $\mathrm{PRO} 2$ & & 75.80 & & 0.3 & 0.608 & \\
\hline Published articles & & $\mathrm{PRO} 4$ & & 77.50 & & 0.6 & 0.528 & \\
\hline $\begin{array}{l}\text { Facebook profile/ } \\
\text { website }\end{array}$ & & PRO5 & & 80.80 & & 0.4 & 0.514 & \\
\hline $\begin{array}{l}\text { Active } \\
\text { relationships with } \\
\text { partners }\end{array}$ & & PRO6 & & 85.80 & & 0.3 & 0.524 & \\
\hline Full time & \multirow[b]{2}{*}{$\begin{array}{l}\text { Employment } \\
(\text { Emp })^{*}\end{array}$} & EMP1 & \multirow{2}{*}{$\begin{array}{l}\text { Ordinal } \\
(1-6) \\
1-5: 1-5 ; \\
6: \text { over } 5 \\
\text { persons }\end{array}$} & 0.17 & 0.71 & 8.8 & 0.837 & 0.830 \\
\hline Part time & & EMP2 & & 0.24 & 0.81 & 9.3 & 0.848 & \\
\hline $\begin{array}{l}\text { Good availability } \\
\text { of workers }\end{array}$ & \multirow{3}{*}{$\begin{array}{l}\text { Human } \\
\text { Resources } \\
\text { (HR) }\end{array}$} & HR1 & \multirow{3}{*}{$\begin{array}{l}\text { Dichoto- } \\
\text { mous } \\
\text { (Yes-No) }\end{array}$} & 73.90 & \multirow{3}{*}{-} & 0.4 & 0.675 & 0.733 \\
\hline $\begin{array}{l}\text { Good } \\
\text { organizational } \\
\text { culture }\end{array}$ & & HR5 & & 89.90 & & 0.5 & 0.760 & \\
\hline $\begin{array}{l}\text { Presence of } \\
\text { fluctuation }\end{array}$ & & HR6 & & 83.10 & & 0.6 & 0.640 & \\
\hline Other funding & \multirow[b]{3}{*}{$\begin{array}{l}\text { State Aid } \\
\text { and Funding } \\
\text { (SAF) }\end{array}$} & SAF2 & \multirow{3}{*}{$\begin{array}{l}\text { Ordinal } \\
(1-4) \\
\text { 1: never; } \\
\text { 2: once; } \\
\text { 3: 2-6 } \\
\text { times; } 4 \text { : } \\
\text { over 6 } \\
\text { times }\end{array}$} & 1.43 & 0.92 & 8.1 & 0.563 & 0.854 \\
\hline State aid & & SAF4 & & 2.30 & 1.16 & 6.8 & 0.900 & \\
\hline $\begin{array}{l}\text { Local government } \\
\text { aid }\end{array}$ & & SAF5 & & 1.73 & 0.9 & 6.9 & 0.931 & \\
\hline Local social effect & \multirow{3}{*}{$\begin{array}{l}\text { Social } \\
\text { Influence } \\
\text { (SI) }\end{array}$} & SI1 & \multirow{3}{*}{$\begin{array}{l}\text { Likert } \\
(1-5) \\
\text { 1: negli- } \\
\text { gible; } \\
5 \text { : very } \\
\text { signi- } \\
\text { ficant }\end{array}$} & 3.70 & 1.79 & 5.1 & 0.612 & 0.833 \\
\hline $\begin{array}{l}\text { Global social } \\
\text { effect }\end{array}$ & & SI2 & & 3.72 & 1.59 & 1.4 & 0.885 & \\
\hline $\begin{array}{l}\text { Relationship with } \\
\text { the local society }\end{array}$ & & SI3 & & 3.69 & 1.59 & 2.6 & 0.847 & \\
\hline
\end{tabular}

Note: ${ }^{\star}$ EMP 3 (Volunteers) has to be removed from the model because the loading was rather low. 
The following six-question blocks were examined: Public Activity (5 items out of the original 8 on a 5 point Likert scale), Professional Activity (5 items out of the original 6 on a dichotomous scale (yes/no)), Employment (2 out of 3 items on an ordinal scale), Human Resources ( 3 items out of the original 6 on a dichotomous scale (yes/no)), State Aid and Funding ( 3 items out of the original 6 on an ordinal scale), Social Influence (3 items out of 6 on a 5 point Likert scale). Composite Reliability was measured by Dillon Goldstein's Rho value which was higher than 0.7 for all the LVs indicating good composite reliability. Only those items were kept whose loading was larger than 0.5 , but the loading was greater than 0.7 in more than $50 \%$ of the items. Public Activity was best described by regular programs (0.873) and management activity (0.828). Professional activity depended on basically the good results from sport (0.666) and other activities (0.608). Among the Human Resource items, Organizational Culture (0.760) was the most influential. State Aid and Funding was best represented by local government aid (0.931), and Social Influence was obviously determined by the global social effect $(0.885)$ the most.

Figure 2 provided a graphical representation of the parameter estimates in the Civil Organization model. PLS-SEM model is an iterative and explanatory technique. Therefore, it can identify irrelevant relationships. For the sake of better understanding, only the statistically significant $(\mathrm{p}<0.05)$ path coefficients were depicted, and non-significant paths indicated by dashed lines.

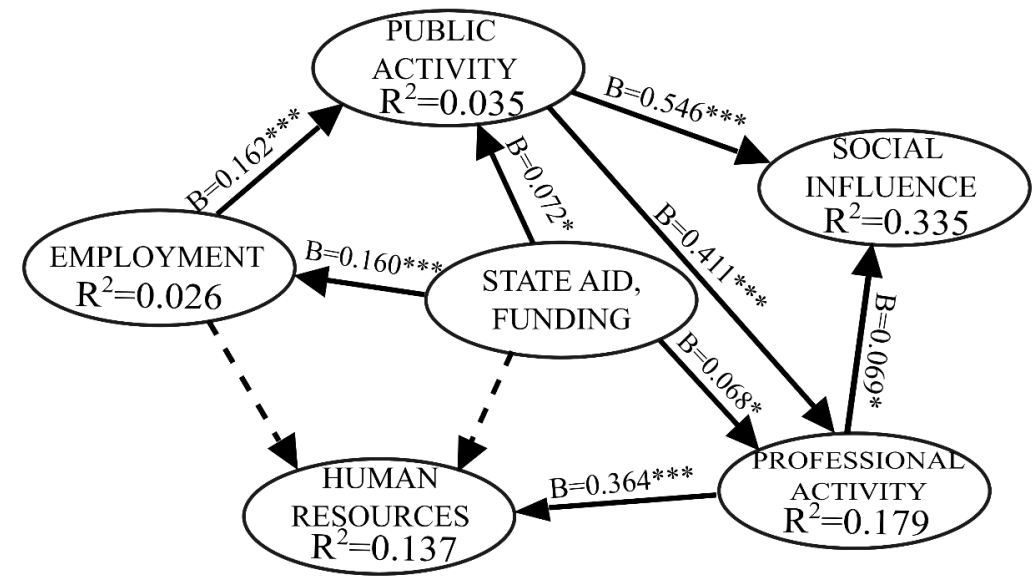

Note: The non-significant paths have been indicated by dotted lines. ${ }^{\star} \mathrm{p}<0.05 ;{ }^{* *} \mathrm{p}<0.01 ;{ }^{* * *} \mathrm{p}<0.001$.

Figure 2. Final Path model and path coefficient estimates

The overall model had a good global fit as the GOF was 0.279 , and the quality of the inner and outer model was also excellent as the normalized GOF was 0.876 and 0.995 . A bootstrapping was also applied for testing the parameter estimation in which 500 samples were drawn from the original data as proposed by Chin (1998). Then the mean and standard error of the path coefficients were estimated, and only those path coefficients were considered statistically significant that were at least twice as much as their standard error. From this fact, the standard errors and $t$ statistics were also provided together with the path coefficients. 
The primary outcome variable, Social Influence had the largest $\mathrm{R}^{2}$ value $(0.335, \mathrm{SE}=0.030$; $\mathrm{t}=11.17 ; \mathrm{p}<0.001)$ but the prediction of the secondary outcome, Professional Activity had also a substantial $\mathrm{R}^{2}$ value $(0.179 ; \mathrm{SE}=0.027 ; \mathrm{t}=6.63 ; \mathrm{p}<0.001)$.

The strongest relationship could be seen between Public Activity and Social Influence $(\mathrm{B}=0.546 ; \mathrm{SE}=0.028 ; \mathrm{t}=19.50 ; \mathrm{p}<0.001)$ and between Public and Professional Activity $(\mathrm{B}=0.411 ; \mathrm{SE}=0.032 ; \mathrm{t}=12.84 ; \mathrm{p}<0.001)$. This indicated that a higher level of Public Activity increased the Social Influence of the civil organization and also boosted Professional Activity.

On the other hand, Professional Activity had also a strong influence $(B=0.364 ; \mathrm{SE}=0.035$; $\mathrm{t}=10.40 ; \mathrm{p}<0.001)$ on Human Resources. State Aid and Funding influenced Employment the best $(\mathrm{B}=0.160 ; \mathrm{SE}=0.036 ; \mathrm{t}=4.44 ; \mathrm{p}<0.001)$ indirectly boosting Public Activity through Employment $(\mathrm{B}=0.162 ; \mathrm{SE}=6.48 ; \mathrm{t}=\mathrm{p}<0.001)$. SAF also had a weaker but significant effect on Public $(\mathrm{B}=0.072 ; \mathrm{SE}=0.030 ; \mathrm{t}=2.40 ; \mathrm{p}=0.017)$ and on Professional Activity $(\mathrm{B}=0.068$; $\mathrm{SE}=0.029 ; \mathrm{t}=2.35 ; \mathrm{p}=0.019)$ but had no influence on Human Resources at all.

The major advantage of PLS-SEM method is that direct, indirect and total effects colud be differentiated on the outcome variable as can be seen in Table 3 .

Table 3. Total, direct and indirect effects and the ratio of the explained variance in Social Influence

\begin{tabular}{|l|c|c|c|}
\hline \multirow{2}{*}{ Relationship } & \multicolumn{3}{|c|}{ Effects* } \\
\cline { 2 - 4 } & Direct & Indirect & Total \\
\hline SAF -> EMP & 0.160 & 0.000 & 0.160 \\
\hline SAF -> PA & 0.072 & 0.026 & 0.098 \\
\hline SAF -> PRO & 0.068 & 0.040 & 0.108 \\
\hline SAF -> HR & 0.047 & 0.034 & 0.081 \\
\hline SAF -> SI & $\mathbf{0 . 0 0 0}$ & $\mathbf{0 . 0 6 1}$ & $\mathbf{0 . 0 6 1}$ \\
& $(\mathbf{0} \%)$ & $(33 \%)$ & $(7.7 \%)$ \\
\hline EMP -> PA & 0.162 & 0.000 & 0.162 \\
\hline EMP -> PRO & 0.000 & 0.067 & 0.067 \\
\hline EMP -> HR & 0.037 & 0.024 & 0.061 \\
\hline EMP -> SI & $\mathbf{0 . 0 0 0}$ & $\mathbf{0 . 0 9 3}$ & $\mathbf{0 . 0 9 3}$ \\
\hline PA -> PRO & $(\mathbf{0 \% )}$ & $(\mathbf{5 1} \%)$ & 0.411 \\
\hline PA -> HR & 0.411 & 0.000 & 0.150 \\
\hline PA -> SI & 0.000 & 0.150 & $\mathbf{0 . 5 7 5}$ \\
\hline PRO -> HR & $\mathbf{0 . 5 4 6}$ & $\mathbf{0 . 0 2 8}$ & $(72 \%)$ \\
\hline PRO -> SI & $(\mathbf{8 9 \% )}$ & $(\mathbf{1 6 \% )}$ & 0.364 \\
\hline Total on SI & 0.364 & 0.000 & $\mathbf{0 . 0 6 9}$ \\
\hline (\%) & $\mathbf{0 . 0 6 9}$ & $\mathbf{0 . 0 0 0}$ & $\mathbf{0 . 7 9 8}$ \\
\hline
\end{tabular}

Note: SAF - State Aid and Funding; EMP - Employment; PA - Public Activity; PRO - Professional activity; HR - Human Resource; SI - Social Influence. * effect percentages in a column sum up to $100 \%$ and are given as the ratio of explained variance in SI. 
Total effects on Social Influence could be divided into direct (77\%) and indirect effects (23\%). Regarding only the direct effects, Public Activity was the most influential variable causing $89 \%$ of the direct effects while Professional Activity contributed only $11 \%$ to the directs effects. Among indirect effects Employment had the strongest effect on Social Influence (51\%) while State Aid and Funding was the second most influential (33\%). Analysing the total effects, we observed that Public Activity constituted $72 \%$ and Employment $11.7 \%$ of the total explained variance in Social Influence. Professional Activity and State Aid and Funding had only a little but significant effect on the Social Influence constituting $8.6 \%$ and $7.7 \%$ of the explained variance. These result were consistent with the previous findings. Babiak and Wolfe (2009) studied for example the corporate social responsibility (CSR) for professional sport organizations and its external and internal determinants. They have found that the primary drivers of CSR in these organizations were rather external determinants (like Public Activity used within this study), while internal pressures (like Professional Activity used in the present paper) were rare and inimitable (Babiak \& Wolfe, 2009). However Robertson et al. (2019) stated that the highest responsibility scores were obtained in the human rights and labour practice dimensions and also in the economic dimension with respect to Community Sport Oragnizations. This was also reflected in the findings of the present research as there was a strong indirect effect of Employments and State Aid and Funding on Social Influence.

Table 4. AVE values (in the main diagonal) and Fornell - Larcker test of discriminant validity

\begin{tabular}{|l|c|c|c|c|c|c|}
\hline Latent variable & SAF & EMP & PA & PRO & HR & SI \\
\hline SAF & $\mathbf{6 6 . 4}$ & $<0.001$ & 0.002 & $<0.001$ & 0.010 & $<0.001$ \\
\hline EMP & 0.025 & $\mathbf{7 1 . 0}$ & $<0.001$ & 0.001 & 0.791 & $<0.001$ \\
\hline PA & 0.010 & 0.030 & $\mathbf{6 2 . 2}$ & $<0.001$ & $<0.001$ & $<0.001$ \\
\hline PRO & 0.012 & 0.011 & 0.175 & $\mathbf{3 2 . 6}$ & $<0.001$ & $<0.001$ \\
\hline HR & 0.007 & 0.001 & 0.139 & 0.134 & $\mathbf{4 8 . 1}$ & $<0.001$ \\
\hline SI & 0.028 & 0.032 & 0.331 & 0.088 & 0.066 & $\mathbf{6 2 . 5}$ \\
\hline
\end{tabular}

Note: SAF - State Aid and Funding; EMP - Employment; PA - Public Activity; PRO - Professional activity; HR - Human Resource; SI - Social Influence; AVE - Average Variance Extracted.

Table 4 showed the AVE values on the diagonal and the squared intervariable correlations under the main diagonal, while the p-values can be seen above the diagonal. Fornell and Larcker (1981) criterion provided evidence of discriminant validity as all AVE values for the LVs were higher than the squared intervariable correlations. It can also be seen that AVE values were greater than 0.5 in the case of the main outcome variables (PA, SI); hence the model was strongly adequate.

\section{Conclusions}

The management of sport civil organizations required the combination of several interrelating factors. Within the study framework Public Activity, Professional Activity, Employment, Human Resources, State Aid and Funding and Social Influence have been used and their 
relationships were also studied throughout a structural path model. A categorical principal component analysis was applied before the path modelling and seemed very suitable for this problem to form the path model and identify the relevant factors. The analysis revealed that regular programs best described Public Activity, Professional Activity depended on mostly the good results of sport; Human Resources could be well characterized by Organizational Culture, while State Aid and Funding were best represented by local government aid and the global social effect played the most part in Social Influence. The overall model had an excellent global fit, and the parameters have been validated by a bootstrapping procedure. The major focus was on the effects of the factors on social influence. The significant advantage of the path model was to detect direct and indirect effects.

Based on the path model, it could be stated that $77 \%$ of all effects were direct, and Public Activity was the most influential on Social Influence with $89 \%$. Regarding the indirect effects, the most critical factors were Employment and State Aid and Funding. Based on the above-mentioned facts, the conclusion of the study was that irrespective of the high dependence on subsidies, sport civil organizations' social influence depended mostly on their public activity and their employees' vocation. In Hungary, in 2018, the dependency of sport-related NGOs on subsidies was high (69.9\%), and $60.8 \%$ come from the state. This dependency largely influenced almost all the activities of these organizations and raised specific questions in the professional operation. Funds contributed to better employment conditions (equally to employees and volunteers), through which professional activity resulted in public activity and social influence. Therefore, a particular emphasis should be placed on launching more regular programs and more advanced human resource management. On the other hand, sport civil organizations should strive for better publicity and transparency in order to improve communication with the public as well as with partners. The special relationship between the activities also explained a reason for that: better Publicity and improved communication contributed to better employment conditions (for example easier accessibility to volunteers) and to better access to the state supports such as the availability to the $1 \%$ tax ratio provided by the taxpaying citizens' annual taxes. Here, publicity and communication were vital to achieving this grant ${ }^{1}$ (this is a special subsidy form here in Hungary open for civic organizations, and since it is based on the offer by taxpayers, its amount is largely affected by the publicity and communication). The managerial approach to these activities should be - owing to this all -treated as the complexity of the possibilities, where the interaction of these activities and their proper practice might equally contribute to better or lower performance.

\footnotetext{
${ }^{1}$ Gerő (2012) in his study described the most important ways of civic engagement in Hungary. One of its indicators among the organization and action-like participation is the engagement in the contribution of the $1 \%$ of the personal income tax, which is a specific, governmental regulated subsidy form/grant. The 1996 CXXVI. Act on the use of a specified part of personal income tax at the disposal of the taxpayer rules that the taxpayer in Hungary is eligible to offer $1 \%$ of the paid income tax to any civic organizations or distinctive governmental charity funds in the annual tayation return and provision. Since taxpayers can freely select any operating domestic civic organizations as a destionation of this tax ratio, the acknowlegement, the social background, the communication and the promotion of a civic organization is vital so as to inform and convince taxpayers through the media, formal and informal communicational channels that they are the best beneficiaries of this grant/donation where this offer will be utilized the best. According to a latest relevant source (Ado Online, 2019), 1689334 taxpayers offered 8773 681598 Fts to 27.634 civic organizations, where on average 1 civic organization received 317496 Fts.
} 
The limitation of these findings was in connection with the sample itself. The 1000 item sample represents the whole sport civic population by settlement and county-related variables. Increasing the representativeness level by involving more variables could have made the sample finer. Despite the fact that sample was blocked by the surveying practice, the results provided a reliable picture of the sport civic sphere. As explained in the methodology part, this was the only option to assemble a database for this purpose. This picture of the activity relationships reflected a cross-sectional state of the art of the Hungarian conditions and might provide more up to date information about the sphere since there is no current official statistics here. The one provided by the Hungarian Statistical Office was 2 years late with the publication of the data of the non-profit and civic organizations (the latest database and brief of this sector was only available from the year of 2018) and will not have an appropriate insight into the current activity of the sport-related civic organizations.

This topic holds some interesting future prospects as well. As a general phenomenon, donation/subsidy dependency may also worth further considerations. The role of large funds in the improvement of the sports organizations can also be studied on a longitudinal basis. Lately, the Hungarian TAO system ${ }^{2}$ now seems to undergo some serious changes. One future direction could be the study of the possible influences on the major sports actors' operating conditions. Lastly, the university and academic sports (namely the professional sports) now seems to gain a new but considerable attention from the government. The university related sports NGOs as well as their sports management also worth professional consideration and further researches.

\section{Acknowledgements}

This publication was prepared in the framework of the EFOP-3.6.2-16-2017-00003 project. The project was established with the support of the European Union, with the co-financing of the European Social Fund.

\section{Author contributions}

SK, GYNSZ and ÉBB conceived the study, GYNSZ was responsible for conceptualization, SK was responsible for the research methods, and data analysis, GYNSZ and KV were responsible for literature review, data analysis, ZB, KP, VF, AH and BBÉ were responsible for data collection and data analysis, GYNSZ and ÉBB were responsible for data interpretation.

\section{Disclosure statement}

The authors declare no conflict of interest.

\footnotetext{
2 TAO-Corporate Tax, until now for-profit organizations may select between paying this tax to the governmental budget or offering it as a donation to foster the operation of large, spectacular sports. The recipients usually were sports organizations, mostly sports NGOs.
} 


\section{References}

ACT CLXXII. (2011). 2011. évi CLXXII. törvény a sportról szóló 2004. évi I. törvény módositásáról. Retrieved December 06, 2021, from https://mkogy.jogtar.hu/jogszabaly?docid=a1100172.TV

Ado Online. (2019). Idén kevesebb adózótól több civil szervezet részesült az egyszázalékos támogatsából. Retrieved June 16, 2021, from https://ado.hu/ado/iden-kevesebb-adozotol-tobb-civil-reszesult-azegyszazalekos-tamogatsabol/

Amato, S., Esposito Vinzi, V., \& Tenenhaus, M. (2004, March 24). A global goodness-of-fit index for PLS structural equation modeling. Oral Communication to PLS Club, HEC School of Management. France.

Andreff, W. (2009, June 29 - July 3). Public and private sport financing in Europe: The impact of financial crisis. In $84^{\text {th }}$ Western Economic Association International Conference (pp. 1-37). Vancouver. Retrieved February 18, 2020, from https://www.researchgate.net/publication/289127093_Public_and_private_sport_financing_in_Europe_the_impact_of_financial_crisis

Andreff, W., \& Szymanski, S. (Eds.). (2007). Handbook on the economics of sport. Edward Elgar Publishing Inc. https://doi.org/10.4337/9781847204073

Arnett, D. B., Laverie, D. A., \& Meiers, A. (2003). Developing parsimonious retailer equity indexes using partial least squares analysis: A method and applications. Journal of Retailing, 79(3), 161-170. https://doi.org/10.1016/S0022-4359(03)00036-8

Auld, C., \& Cuskelly, G. (2012). Managing sport in the nonprofit sector. In L. Trenberth \& D. Hassan, Managing sport business: An introduction (pp. 79-96). Routledge.

Babiak, K., \& Wolfe, R. (2009). Determinants of corporate social responsibility in professional sport: Internal and external factors. Journal of Sport Management, 23(6), 717-742.

https://doi.org/10.1123/jsm.23.6.717

Bácsné Bába, É., Fenyves, V., Szabados, G., Peto, K., Bács, Z., \& Dajnoki, K. (2018). Sport involvement analysis in Hungary, in the North Great Plain Region. Sustainability, 10(5), 1629. https://doi.org/10.3390/su10051629

Bodnár, I., \& Perényi, S. (2012). A socio-historical approach to the professionalization of sporting occupations in Hungary during the first decades of the twentieth century: The coach. International Journal of the History of Sport, 29(8), 1097-1124. https://doi.org/10.1080/09523367.2012.666971

Breuer, C., Feiler, S., Llopis-Goig, R., \& Elmose-Østerlund, K. (2017). Characteristics of European sports clubs: A comparison of the structure, management, voluntary work and social integration among sports clubs across ten European countries. Centre for Sports, Health and Civil Society, University of Southern Denmark.

Calhoun, C. (1993). Civil society and the public sphere. Public Culture, 5(2), 267-280. https://doi.org/10.1215/08992363-5-2-267

Chin, W. (1998). The partial least squares approach to structural equation modeling. In G. Marcoulides, Modern methods for business research (pp. 295-336). Lawrence Erlbaum Associates.

Cohen, J. (1988). Statistical power analysis for the behavioral sciences (2 $2^{\text {nd }}$ ed.). Lawrence Erlbaum Associates.

Cordery, C., \& Baskerville, R. (2011). Understanding the significance of revenue diversification in nonprofit sports clubs. SSRN. https://doi.org/10.2139/ssrn.1634476

Daft, R. (2010). Management ( $9^{\text {th }}$ ed.). South-Western, Cengage Learning.

Dajnoki, K., Fenyves, V., Bácsné Bába, É., Kőmíves, P. M., \& Szabados, G. N. (2020). The characteristics of civil organizations for sports with special regards to employment. International Journal of Engineering and Management Sciences, 5(1), 701-711. https://doi.org/10.21791/IJEMS.2020.1.58 
Development Initiatives. (2015). Global humanitarian assistance report 2015. Development Initiatives, Bristol. Retrieved October 04, 2020, from http://devinit.org/wp-content/uploads/2015/10/ GHA2015P_Friendly2.pdf

Diamantopoulos, A. (1999). Export performance measurement: Reflective versus formative indicators. International Marketing Review, 16(6), 444-457. https://doi.org/10.1108/02651339910300422

Ekholm, D., \& Dahlstedt, M. (2019). Forming the association-like organization: On civil society, welfare provision and sport as a means of social inclusion. International Journal of the Sociology of Leisure, 2, 219-238. https://doi.org/10.1007/s41978-018-0019-5

Esposito Vinzi, V., Trinchera, L., \& Amato, S. (2010). PLS path modeling: From foundations to recent developments and open issues for model assessment and improvement. In V. Esposito, W. Chin, J. Hensler, \& H. Wang (Eds.), Handbook of partial least squares: Concepts, methods, applications (pp. 47-82). Springer. https://doi.org/10.1007/978-3-540-32827-8_3

European Commission. (2018). Special Eurobarometer 472: Sport and physical activity (Wave EB88.4). Directorate-General for Education, Youth, Sport and Culture, Brussels.

European Commission. (2020). Civil society and the 2030 Agenda. Retrieved December 6, 2021, from https://europa.eu/capacity4dev/file/102562/download?token=onLH6j1X

Fornell, C., \& Larcker, D. F. (1981). Evaluating structural equation models with unob-servable variables and measurement error. Journal of Marketing Research, 18(1), 39-50.

https://doi.org/10.1177/002224378101800104

Fornell, C., Johnson, M. D., Anderson, E. W., Cha, J., \& Bryant, B. E. (1996). The American customer satisfaction index: Nature, purpose, and findings. Journal of Marketing, 60(4), 7-18. https://doi.org/10.1177/002224299606000403

Garson, G. D. (2016). Partial least squares regression and structural equation models. Statistical Associates Publishers.

Gerő, M. (2012). A civil társadalom néhány trendje Magyarországon 199 után. In I. Kovách, C. Dupcsik, P. Tóth Tamás, \& J. Takács (Eds.), Társadalmi integráció a jelenkori Magyarországon. Tanulmányok (pp. 317-342). MTA Társadalomtudományi Kutatóközpont (Szociológiai Intézet). Argumentum Kiadó, Bp. https://mek.oszk.hu/12700/12706/12706.pdf

Griffin, R. (2013). Management (1 $1^{\text {th }}$ ed.). South-Western Cengage Learning, Mason.

Habermas, J. (1989). The structural transformation of the public sphere: An inquiry into a category of Bourgeois Society. MIT Press.

Hair, J., Hult, G., Tomas, M., Ringle, C., \& Sarstedt, M. (2014). A primer on partial least squares structural equation modeling (PLS-SEM) ( $2^{\text {nd }}$ ed.). SAGE Publications.

Helmig, B., Jegers, M., \& Lapsley, I. (2004). Challenges in managing nonprofit organizations: A research overview. International Journal of Voluntary and Nonprofit Organizations, 15(2), 101-116. https://doi.org/10.1023/B:VOLU.0000033176.34018.75

Hemphill, T. (2013). The ISO 26000 guidance on social responsibility international standard: What are the business governance implications? Corporate Governance: The International Journal of Business in Society, 13(3), 305-317. https://doi.org/10.1108/CG-08-2011-0062

Horch, H. D. (2018). The intermediary organizational structure of voluntary associations. Voluntary Sector Revie, 9(1), 55-72. https://doi.org/10.1332/204080518X15199961331653

Ibsen, B. (2006). Foreningsidrcetten i Danmark: udvikling og udfordringer [Voluntary organized sport in Denmark: Development and challenges]. Syddansk Universitet for Idrættens Analyseinstitut, Center for forskning i Idræt, Sundhed og Civilsamfund, Copenhagen.

Kozma, G. (2017). Spatial characteristics of sports-related non-profit organizations in Hungary. GeoSport for Society, 6(1), 22-29. 
Központi Statisztikai Hivatal. (2018). A nonprofit szektor legfontosabb jellemzöi 2018-ban. Statisztikai Tükör 2019.12.23. KSH. Retrieved August 09, 2020, from https://www.ksh.hu/apps/shop. kiadvany?p_kiadvany_id=1050994\&p_lang=HU

Kuti, É. (1993). Defining the nonprofit sector: Hungary. In L. M. Salamon \& H. K. Anheier, Working papers of the Johns Hopkins comparative nonprofit sector project. The Johns Hopkins Institute for Policy Studies.

Linting, M., Meulman, J., Groenen, P., \& van der Kooij, A. (2007). Nonlinear principal components analysis: Introduction and application. Psychological Methods, 12(3), 336-358. https://doi.org/10.1037/1082-989X.12.3.336

Lynn, E. (2013). The road to financial sustainability: How managers, government, and donors in Africa can create a legacy of viable public and non-profit organizations (Technical Paper No. 85).

Natil, I., Malila, V., \& Sai, Y. (Ed.). (2021). Barriers to effective civil society organization. Political, social and financial shifts. Routledge. https://doi.org/10.4324/9781003053040

Nicholson, M., \& Hoye, R. (2008). Sport and social capital: An introduction. In M. Nicholson \& R. Hoye (Eds.), Sport and social capital (pp. 1-20). Elsevier Ltd. https://doi.org/10.4324/9780080569727

O'Neil, M. (1989). The third America: The emergence of the nonprofit sector in the United States. Jossey Bass, San Francisco, California.

Osterlund, K. (2013). Managing voluntary sport organizations to facilitate volunteer recruitment. European Sport Management Quarterly, 13(2), 143-165. https://doi.org/10.1080/16184742.2012.731074

Perényi, S. (2020). Hungary: Potentials for civil initiatives in sports. In S. Nagel, K. Elmose-Østerlund, B. Ibsen, \& J. Scheerder (Eds.), Sports economics, management and policy: Vol. 13. Functions of sports clubs in European societies: A cross-national comparative study (pp. 151-182). Springer. https://doi.org/10.1007/978-3-030-48535-1_7

Perényi, S., \& Bodnár, I. (2015). Sports clubs in Hungary. In C. Breuer, R. Hoekman, S. Nagel, \& H. van der Werff (Eds.), Sports economics, management and policy: Vol. 12. Sport clubs in Europe. A cross-national comparative perspective (pp. 221-247). Springer. https://doi.org/10.1007/978-3-319-17635-2_13

R Core Team. (2019). R: A language and environment for statistical computing. R Foundation for Statistical Computing, Vienna. https://www.R-project.org

Robbins, S., \& Coulter, M. (2012). Management (11 $1^{\text {th }}$ ed.). Pearson Education, Inc.

Robertson, J., Eime, R., \& Westerbeek, H. (2019). Community sports clubs: Are they only about playing sport, or do they have broader health promotion and social responsibilities? Annals of Leisure Research, 22(2), 215-232. https://doi.org/10.1080/11745398.2018.1430598

Salamon, L. M., \& Anheier, H. K. (1992). In search of the nonprofit sector I: The question of definitions. International Journal of Voluntary and Nonprofit Organizations, 3(2), 125-151. https://doi.org/10.1007/BF01397770

Sanchez, G. (2013). PLS path modeling with R. Trowchez editions. Berkeley. http://www.gastonsanchez. com/PLSPathModelingwithR.pdf

Saukani, N., \& Ismail, N. A. (2019). Identifying the Components of Social Capital by Categorical Principal Component Analysis (CATPCA). Social Indicators Research, 141, 631-655. https://doi.org/10.1007/s11205-018-1842-2

Seippel, $\varnothing$. (2004). The world according to voluntary sport organizations. International Review for the Sociology of Sport, 39(2), 223-232. https://doi.org/10.1177/1012690204043465

Seippel, $\varnothing$. (2005). Sport, civil society and social integration: The case of Norwegian voluntary sport organizations. Journal of Civil Society, 1(3), 247-265. https://doi.org/10.1080/17448680500484483

Seippel, Ø. (2006). Sport and social capital. Acta Sociologica, 49(2), 169-183.

https://doi.org/10.1177/0001699306064771 
Soares, J. P., Antunes, H. L., Barbara, A., Escorcio, C., \& Saldanha, P. (2016). The public interest of sports at non-profit sports organizations that are supported by the government. Revista Brasileira de Educação Física e Esporte, 30(3), 689-702. https://doi.org/10.1590/1807-55092016000300675

Strittmatter, A.-M., Hanstad, D. V., \& Skirstad, B. (2021). Facilitating sustainable outcomes for the organization of youth sports through youth engagement. Sustainability, 13(4), 2101. https://doi.org/10.3390/su13042101

Szabados, G. N., Bácsné Bába, É., Fenyves, V., Bács, Z., Dajnoki, K., \& Kovacs, S. (2019). Sportcivil szervezetek es az emberi eroforrasok osszefüggese [The relationship between sports civic organizations and hüman resources]. International Journal of Engineering and Management Sciences, 4(3), 146-154. https://doi.org/10.21791/IJEMS.2019.3.14.

Szabados, G. N., Bácsné Bába, É., Fenyves, V., Bács, Z., Helmeczi, A., \& Dajnoki, K. (2020). Sportcivilekellenőrzés, beszámolási sajátosságok [Civic Organizations, sports civic organizations and the control]. International Journal of Engineering and Management Sciences (IJEMS), 5(1), 289-299. https://doi.org/10.21791/IJEMS.2020.1.25

Tuckman, H. P., \& Chang, C. F. (1991). A methodology for measuring the financial vulnerability of charitable nonprofit organizations. Nonprofit and Voluntary Sector Quarterly, 20(4), 445-460. https://doi.org/10.1177/089976409102000407

Weber, M. (1993). From Max Weber: Essays in sociology. Routledge.

Wetzels, M., Odekerken-Schröder, G., \& Van Oppen, C. (2009). Using PLS path modeling for assessing hierarchical construct models: Guidelines and empirical illustration. MIS Quarterly, 33(1), 177-195. https://doi.org/10.2307/20650284

Wicker, P., Longley, N., \& Breuer, C. (2015). Revenue volatility in Greman nonprofit sports clubs. Nonprofit and Voluntary Sector Quarterly, 44(1), 5-24. https://doi.org/10.1177/0899764013499072

World Alliance for Citizen Participation. (2021). State of civil society report 2021. CIVICUS. Retrieved August 19, 2021, from https://reliefweb.int/report/world/state-civil-society-report-2021-enarpt

Wold, H. (1982). Soft modeling: The basic design and some extensions. In K. G. Joreskog \& H. Wold (Eds.), Systems under indirect observation, Part 2. North-Holland.

Wold, H. (1985). Partial least squares. In S. Kotz \& N. L. Johnson, Encyclopedia of statistical sciences (pp. 581-591). Wiley.

Vosyliūte, L., \& Luk, N. C. (2020). Protecting civic society space: Strenghtening freedom of association, assembly and expression and the right to defend rights in the EU. Retrieved August 19, 2021, from https://www.europarl.europa.eu/RegData/etudes/STUD/2020/659660/IPOL_STU(2020)659660_ EN.pdf 